DOI: https://doi.org/10.32839/2304-5809/2021-4-92-14

УДК 811.131.1+811.161.1'25

Вернигора Д.О.

Київський національний університет імені Тараса Шевченка

\title{
ОСОБЛИВОСТІ ПЕРЕКЛАДУ ІТАЛІЙСЬКИХ АВТОРСЬКИХ КАЗОК УКРАЇНСЬКОЮ МОВОЮ
}

\begin{abstract}
Анотація. У статті досліджено підходи до визначення жанру казки в італійському та українському літературознавстві, характерні структурні елементи, ффункції та лексичні особливості літературних або авторських казок у порівнянні з фольклорними або народними казками, а також розглянуто жанровостилістичні домінанти авторських казок в контексті дитячої літератури, які необхідно враховувати при перекладі. Крім того, у цій публікації систематизовано характерні риси та відмінності італійського та українського казкового дискурсу, проаналізовано стратегії перекладу та перекладацькі трансформації, застосовані для відтворення інціальних та фрінальних формул, “формул неможливого”, реалій і гри слів італійських авторських казок українською мовою на матеріалі збірки видатного італійського письменника Джанні Родарі "Казки по телефону”.
\end{abstract}

Ключові слова: казка, літературна казка, авторська казка, фольклорна казка, народна казка, жанровостилістична домінанта, переклад, перекладознавство, перекладацькі трансформації.

Vernyhora Daria Kyiv Taras Shevchenko National University

\section{PECULIARITIES OF TRANSLATION OF ITALIAN AUTHOR'S FAIRYTALES INTO UKRAINIAN LANGUAGE}

Summary. The article is devoted to the problem of translation of Italian author's or literary tales. This issue is relevant for Translation Studies due to the complexity of the genre, as it reflects conceptual, linguistic, linguocultural picture of the world connected with individual picture of the world and artistic style of the author, also it can contain national specific elements, symbolism and particular structure of the text that can be different from culture to culture, and translator is ought to be aware of it. In this research the definition of the tale in Italian and Ukrainian Literature Studies is examined; the comparison between folk or popular tale and literary or author's tale is given; main characteristics, functions and structure of the author's tale are investigated; the role of author's or literary tale in children's literature is highlighted. The research is based on the collection of Italian literary tales "Favole al telefono" written by Gianni Rodari and translated into Ukrainian language by Ivan Dzjub. The article features linguocultural and translation analysis of the original, strategies and approaches of the translation of introduction and ending phrases, toponyms and anthroponyms, realia and pun applied by Ivan Dzjub. It is concluded that the au-tor's or literary tale is based on folk tale, literary tale adopts the structure and clichés of folk tale and enriches it with detailed description of characters, modern terminology and realia, allusions to famous literature works. In both Italian and Ukrainian culture literary tales are more likely associated to and strongly connected with children's literature, so it is important to take into account children's psychology and expectations from the genre, when translating. The translator has chosen between two principal translation strategies, foreignization and domestication, according to the relevance of a single component to the entire meaning of the text, trying to preserve national specificity of the original and avoid significant adaptations, except for several cases of the compression of ending phrases determined by Ukrainian folk tradition.

Keywords: translation studies, translation strategies, literary tales, folk tales, Italian literary tales, linguoculturology, foreignization, domestication, conceptual picture of the world, linguistic picture of the world, main strategies and methods of translation, cultural adaptation.

Постановка проблеми. Казка є одним 3 найдавніших та найпоширені-ших жанрів літератури, що має власні закони та особливості, які необхідно враховувати при перекладі. Дослідження стратегій та підходів до перекладу текстів цьог жанру набуває значної актуальності з огляду на панівну антропоцентричну парадигму у сучасній лінгвістищі, адже через жанр казки можливо дослідити мовну, концептуальну та лінгвокультурну картини світу, а також зважаючи на розвиток жанрової теорії перекладу, оскільки казки різних народів світу можуть відрізнятися за жанрово-стилістичними домінантами та фрункціями. Авторська казка $є$ особливим випадком перекладу казок, адже при їх відтворенні важливо зважати й на індивідуально-авторський стиль письменника.

Аналіз останніх досліджень і публікацій. Значний внесок у дослідження лінгвопоети- ки казок здійснили О.І. Нікіфроров, В.Я. Пропп, Л.Ф. Дунаєвська, Л.Н. Овчиннікова, які подали визначення та описали характерні риси цього жанру. Дослідженню перекладів казок присвятили свої праці М.Н. Венгренівська, Н.I. Кушина, O.I. Шевченко, Н.I. Лєпухова, які проаналізували особливості відтворення композиційних та лінгвокультурологічних особливостей фрранцузьких, іспанських, німецькаих, англійських та українських народних та авторських казок.

Виділення невирішених раніше частин загальної проблеми. Дослі-дження перекладів італійських казок українською мовою на сьогоднішній день не можна вважати вичерпним, не зважаючи на значну чисельність перекладів, здійснених видатними українськими перекладачами та лінгвістами. Крім того, важливим аспектом дослідження є також і фрункціональні особли- 
вості італійських казок, що впливають на стратегї та підходи при їх відтворенні українською мовою.

Формування цілей статті. Головним завданням цього дослідження є аналіз спільних та відмінних рис фольклорної або народної казки та літературної або авторської казки і дослідження жанрово-стилістичних домінант, які впливають на процес перекладу авторських казок. Також пропонується виконати лінгвокультурологічний та перекладознавчий аналіз стратегій та прийомів, що застосовуються при відтворенні італійських авторських казок українською мовою на основі збірки авторських казок видатного італійського письменника Джанні Родарі "Favole al telefono" (1962р.) [10] та її перекладу українською мовою, здійсненого у 1977 р. Іваном Петровичем Дзюбом та опублікованого видавництвом "Веселка" під назвою "Казки по телефону" [18].

Виклад основного матеріалу. Перш за все пропонуемо розглянути, як визначае жанр казки сучасне українське літературознавство. “Словник сучасної української мови” подає наступне тлумачення: казка - 1. Це розповідний народно-поетичний або писемно-літературний твір про вигадані події, вигаданих осіб, іноді, за участю франтастичних сил. 2. Те, що не відповідає дійсності; вигадка, байка. Таким чином, можна виокремити наступні характерні ознаки цього жанру: казка є оповіддю та вигадкою. Це підтверджується визначенням, яке сорормулювали І. Больте та Г. Полівка: "Під казкою розуміють оповідь, засновану на поетичній фонтазії, зокрема на франтазії щодо чарівного світу; історію, що не пов'язана з умовами реального життя, усі верстви суспільства слухають із задоволенням, навіть якщо вважають її неймовірною та невірогідною" [1]. У нашому дослідженні ми керуватимемося визначенням профресора Л.Ф. Дунаєвської: казка - це оповідання чарівно-франтастичного, алегоричного і соціально-побутового характеру зі своєрідною системою художніх засобів, підпорядкованих героїзації позитивних, сатиричному викриттю негативних образів, часто гротескному зображенню їх взаємодії [6, с. 6-15].

В італійському літературознавстві існують два терміни на позначення казки - fiaba та favola. Fiaba - це франтастична оповідь, що має народне походження та усну традицію побутування; в оповіді взаємодіють люди та надприродні істоти такі, як маги, фреї, відыми, гноми, орки, гіганти і т.д. [5, c. 377]. Favola - це літературний жанр, що являе собою коротку прозову або віршовану оповідь, метою якої є повчання; головними діючими особами такої оповіді $є$ тварини або неживі істоти, які уособлюють людські вади та чесноти; такий тип оповіді було започатковано у VI ст. до н.е. Езопом [7]. Отже, термін fiaba є ближчим до українського визначення казки, в той час, як термін favola означає явище, подібне до української байки. Адже байкаце коротке, переважно віршоване, алегоричне оповідання, в якому закладено дидактичний зміст; один 3 різновидів ліро-епічного жанру. Складаеться з оповідної частини та висновку-повчання. У вчинках персонажів байки - звірів, птахів, рослин вбачаються і висміюються людські вади. [13, с. 74-75]. Втім, дуже поширеним $є$ вибір терміну fiaba на позначення народної казки та favola - авторської.

Спираючись на дослідження О.I. Нікіфорова [15], В.Я. Проппа [17] та Л.Ф. Дунаєвської [6] мо- жемо зазначити, що до основних фрункцій жанру казки належать: естетична, що полягає у яскравому зображенні подій, гіперболізації фрізичних і духовних якостей персонажів; впливова, що постає у здатності викликати у реципієнта почуття; розважальна - адже казка розповідае про надзвичайні події; виховна - тобто наявність повчання, або моралі, що, втім, не є основним завданням твору.

Безперечно, найдавнішим є жанр фольклорної або народної казки, який від початку складав усну народну творчість і був поширеним ще у Стародавньому Китаї, Індії, Єгипті, у Античному світі.

До характерних рис фольклорної або народної казки відносяться: узагальнена згадка про епоху та місце подій; наявність чарівних елементів; відсутність портретного опису героїв; персонажі є стереотипізованими архетипами, що протиставляються; повчання; традиційні формули початку та кінця; щасливий кінець; потроення, або триєдність; повтори. Мотиви фрольклорних казок різних народів світу можуть перетинатися або наслідуватися, проте, кожна нація створюе власний сюжет із притаманним їй колоритом.

Відповідно до класифікації В.Я. Проппа, італійські народні казки можна віднести до чарівних, а українські - до побутових та казок про тварин. Крім того, відмінною $є$ й роль фольклорних казок в італійській та українській культурах: в Італї̈ народна казка $є$ елементом етнографії й нечасто використовуеться для читання дітям, а в Україні, навпаки, казка перш за все спрямована на дитячу аудиторію.

Особлива увага до літературної або авторської казки з боку літературознавства з'явилась у 70-х рp. XX ст. В той період авторська казка зазвичай протиставлялася народній. Але згодом все більше дослідників доходили висновку, що літературна казка засновувалась на фольклорній. Таким чином, у нашій науковій розвідщі ми послуговуватимемось визначенням літературної казки, яке запропонувала Л.Н. Овчиннікова: літературна казка - це багатожанровий вид літератури, що реалізуеться у безкінечному розмаїтті творів різних авторів; у кожному з жанрових типів літературної казки наявна своя домінанта (гармонійний образ світу, пригодницькі мотиви, виховний аспект), до якої можуть приєднуватися міфологічні елементи, традиційні для фольклорних казок, легенд [16]. Також літературна казка асомілюе й елементи попередніх літературних традищій, що підтверджуе М.Н. Липовеџький: "Художній світ літературних казок фборлуеться в результаті взаєлодї чарівно-казкової жанрової пал'яті з моделями світу, властивили новил жанрал” [14].

Літературні або авторські казки поділяються на такі різновиди: фольклорно-літературні, тобто ті, що являють собою перекази чи переспіви фольклорних мотивів; та індивідуально-авторські тобто оповіді як результат творчого поштовху письменника, збагачені казковими елементами.

Перші літературні казки з'явилися у XVIII ст. у вигляді переказів та авторських обробок фольклорних мотивів. В той час, як становлення власне авторської казки відбулось у XIX-XX ст., серед найвідоміших авторів - Ш. Перро, Г.Х. Андерсен, В. Гауф, А. Ліндгрен, К. Коллоді, О. Уайльд, Дж. Родарі.

На відміну від народної, авторська казка має конкретизований хронотоп і навіть містить вказів- 
ки, що дія розгортається за сучасних читачеві часів: наприклад, “сале mym, серед нас", що створює так звану “ілюзію достовірності”, тобто органічного вплетення чарівного у сьогодення, що є характерним для авторських казок; у казці наявні елементи чарівності: в авторських казках окрім морально-етичного протистояння добра та зла присутня також і опозиція "свій” - “чужий”, де під “своїм" варто розуміти реальний світ, в якому живуть геpoї, навіть, якщо це королі, принщи та графои, а під “чужим" - чарівні події, дива, також і за участі чарівних істот, наприклад, русалок та драконів. "Чарівне" не може вважатися другорядним, адже самі герої казок не сприймають його другорядним, a, навпаки, ставляться до "чарівного" як до норми, через що реальний та чарівний світи виглядають одним цілим. Герої літературної казки мають складний характер, детально описується їхня 30внішність. Сюжет і композищія авторської казки підпорядковуються франтазії автора й нерідко містять біографрічні елементи. Літературна казка не завжди має щасливий кінець - часто авторська казка завершуеться у більш реалістичному ключі.

Отже, можна зробити висновок, що літературна казка запозичила деякі елементи фрольклорної, зокрема, поетику чарівних подій, окремі сюжети, стилістичні кліше, як-то ініціальні та фрінальні формули, й, власне, сам жанр. Тобто, коли автор робить вибір на користь казки, він певною мірою наслідуватиме традицію цього жанру й включить до твору усталені елементи фольклорної оповіді.

Варто додати, що, як в італійській, так і в українській культурі літературна або авторська казка великою мірою асоціюеться з дитячою літературою, особливості якої необхідно враховувати при перекладі таких творів.

Однією з характерних рис дитячої авторської казки є повчання. Ще на початку XX ст. O.I. Hiкіфроров згадував “педагогічні казки” [15], у яких фольклорні сюжети переосмислювалися 3 педагогічною цілеспрямованістю. Але згодом К.І. Чуковський наголосив на тому, що світ дітей відрізняється від світу дорослих, тож у творах для дітей необхідно це враховувати [20]. Німецький вчений К. Бюлер вивчав зв'язок між віком дитини та жанрами літератури і дійшов висновку, що саме у віці від трьох до тринадцяти років дитина має певні установки, наївність мислення, які дозволяють відчути радість від читання казок, i які із дорослішанням втрачаються [2]. Наявність чарівних елементів, запозичених з фрольклорної традиції, зумовлюється особливостями дитячої психіки, адже діти мають жваву франтазію і після читання або прослуховування починають уявляти себе на місці героїв та розігрувати казкові сюжети. Іншими обов'язковими елементами є протистояння добра та зла і наявність щасливої кінцівки.

При перекладі літературних казок, спрямованих на дитячу аудиторію від перекладача вимагається не лише створити еквівалентний та адекватний переклад, але й застосувати творчий підхід, врахувати особливості аудиторії: тобто, де це необхідно, вдатися до членування речення, щоб переклад міг бути легко сприйнятий дитиною, уникати буквалізму, володіти значним лексичним розмаїттям цільової мови, відтворити національний колорит та індивідуально-авторський стиль вихідного тексту, а також коректно передати образність пере- шотвору, зокрема, відтворити промовисті топоніми та антропоніми, гру слів та гумор.

Для дослідження перекладацьких стратегій при відтворенні італійських авторських казок українською мовою ми обрали збірку Джанні Родарі "Казки по телефрону", адже у назві автор відразу ж повідомляє про те, що він дотримуватиметься певних канонів цього жанру. За сюжетом головний герой та оповідач, синьйор Б'янкі, працюе комівояжером і шість днів на тиждень проводить у робочих подорожах Італією, а його маленька дочка відмовляеться засинати без казки, тож батько щовечора теледронує додому і розповідає нову коротку історію. У нашій розвідщі ми звернемо увагу на особливості відтворення ініціальних та фрінальних формул першотвору, на характер та спосіб відтворення антропонімів, топонімів та реалій.

У деяких казках Родарі формули початку $е$ також і "форомулами неможливого" [4]: Una volta a Bologna, fecero un palazzo di gelato proprio sulla Piazza Maggiore [10] - Одного разу в Болоньї сале на П'яииа Маджоре побудували палаи із морози$\underline{\text { sa [18] та Una volta a Piombino piovvero confetti. }}$ Venivano giù grossi come chicchi di grandine, ma erano di tutti i colori: verdi, rosa, viola, blù [10] - Odного разу в Пйомбіно пішов иукеровий дощ. 3 неба летіли різнобарвні иукерки: $i$ зеленi, $i$ рожевi, $i$ фбіолетові, й блакитні [18]. При перекладі обох ініціальних формулах I.П.Дзюб не подає жодних уточнень щодо топонімів і відтворюе колорит італійської казки завдяки використанню сталих відповідників, транслітерації назви головної площі м.Болонья. Казка "Storia del regno di Mangionia" (“Тсторія королевства Ненажеранії") містить промовисті топоніми: Sul lontano, antico paese di Mangionia, a est del ducato di Bevibuono, regnò per primo Mangione il Digeritore, cosi chiamato perché dopo aver mangiato gli spaghetti sgranocchiava anche il piatto, e lo digeriva a meraviglia [10] - У далекіŭ стародавній краӥні Ненажеранї, шо на сході межує з гериогствол Випиванія, першил королював Ненажера Всетравний, прозваний так через те, шо, виївии макарони, улинав тарілку і чудово все перетравлював [18]. Іван Дзюб при перекладі відтворює семантику обох власних назв.

До формул неможливого відноситься й детальний опис незвичних інтер'єрів, наприклад: Tutto il resto era di gelato: le porte di gelato, $i$ muri di gelato, $i$ mobili di gelato [10] - Все інше було з морозива: $\underline{i}$ дері, i стіни, i меблі [18]. Детальний опис дозволяе створити “ілюзію достовірності”, що органічно поєднує чарівний та реальний світи.

Крім того, "фрормули неможливого" зустрічаються у формулах кінця, які повністю відтворюються при перекладі: Fu un gran giorno, quello, e per ordine dei dottori nessuno ebbe il mal di pancia [10] Ой, який же то був веселий день! До того ж лікарі зробили так, шо ні в кого не болів живіт [18].

У певних випадках Іван Дзюб вдається до компресії при перекладі фрормул кінця, як, наприклад, у казці “А inventare i numeri" ("Хто вигадає більше чисел”): Quanto pesa una lacrima? Secondo: la lacrima di un bambino capriccioso pesa meno del vento, quella di un bambino affamato pesa più di tutta la terra. Quanto è lunga questa favola? - Troppo. [10] - Скільки важить одна сльозина? - Як чия. Як вередунова, то легша за вітер, а як голодної дитини, то важча за иілу 
Зеллю. - Чи довга ия казка? - Аж занадто [18]. У наведеному прикладі висвітлюеться головна ідея твору, але на цьму в оригіналі казка не закінчується, адже герої продовжують вигадувати цифрии, вимовляючи їх подібно до моденьского та римського акцентів, які перекладач не відтворює. Вирогідно, І.П. Дзюб намагався зусередити увагу на дидактичній фрункції казки. Тож можна вважати, що мала місце прагматична адаптація тексту. Фінальні формули містять й повчання: Alice sospirò. Le venne in mente la mamma, che la credeva ancora a letto; le venne in mente il babbo, che proprio quella sera doveva arrivare dalla città, perché era sabato. - Non posso lasciarli soli, mi vogliono troppo bene. Tornerò a terra, per questa volta. [10] - Аліса зітхнула. Згадала милиу. Вона, мабуть, дулає, шо Аліса ше спить. Згадала тата. Сьогодні субота, $i$ ввечері тато має приїхати з міста. - Шкода мені їх кидати. Вони лене так люблять. Цього разу я повернуся на суходіл [18]. Джанні Родарі був не тільки письменником, але й педагогом і вперше свого часу звернувся до дітей, як до рівних, тож невипадковим є складний психологізм образів, як, наприклад, у казці "Alice casca in mare" ("Аліче пірнає в море”), що висвітлює співчуття до батьків та почуття відповідальності за ближнього.

Також пропонуемо зупинити увагу на способах відтворення антропонімів: прості імена, як наприклад Giovannino - Джованніно, Francesco Франческо, Іван Дзюб відтворював шляхом транслітеращії, а промовисті - через експлікацію змісту: Mangione Terzo, detto l'Antipasto; Mangione Quarto, detto Cotoletta alla Parmigiana; Mangione Quinto, il Famelico; Mangione Sesto, lo Sbranatacchini; Mangione Settimo, detto "Ce n'è ancora?", che divorò perfino la corona, e si che era di ferro battuto; Mangione Ottavo, detto Crosta di Formaggio, che sulla tavola non trovò più nulla da mangiare e inghiotti la tovaglia: Mangione Nono, detto Ganascia d'Acciaio, che si mangiò il trono con tutti i cuscini [10]. - Onicля на троні Ненажеранії, шо височів перед столол, заставленил і вдень

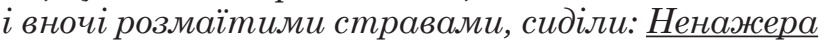
Третій, прозваний Закускою; Ненажера Четвертий, на прізвисько Котлета по-парліджанськи; Ненажера П'ятий, Голодний; Ненажера Шостий, Індикожер; Ненажера Сьомий, прозваний "А ше шо?", який прославився тил, шо з"ї корону з кутого заліза; Ненажера Восьлий, Суха Скоринка, - ией, не знайшовши нічого на столі, проковтнув скатертину; Ненажера Дев'ятий, на прізвисько Сталева Щелепа, з'ї трон разол з подушечкали [18]. Для дитячої літератури є характерною така гіперболізація якостей персонажів, що виноситься до складу їхніх імен.

Також через антропоніми відтворюється й алюзія на жанри італійської літератури, зокрема, Commedia dell'Arte (Комедії масок): Arlecchino non voleva saperne di separarsi da Colombina [10]Та Арлекін нізашо не хотів розлучатися 3 Кололбіною [18]. У цьому випадку І.П. Дзюб також транслітеруе імена героїв і не подає додаткових зносок або коментарів.

Варто зазначити, що часова відстань між створенням тексту оригіналу та тексту перекладу не була значною - лише п'ятнадцять років - що дало змогу перекладачеві відтворювати деякі більш складні реалї без додаткових роз'яснень: Adesso era un'automobile da corsa, tutta rossa, col numero scritto in bianco sul cofano, e il cortile una pista rombante [10] - Тепер ие вже був червоний спортивний автолобіль з білил нолерол на капоті. Подвір'я перетворилося на доріжку для перегонів [18]; Poi il bastone fu un motoscafo, e il cortile un lago dalle acque calme e verdi [10] - Згодол палиия перетворювалася на моторний човен, а подвір'я в спокійне зеленаве озеро" [18]; "e poi un'astronave che fendeva lo spazio, lasciandosi dietro una scia di stelle [10] - a modi cmaла зорянил кораблел, який розтинав космічний простір, минаючи небесні світила [18].

Також Джанні Родарі вводить у текст казки такі історичні реалії, як партизан, що відтворюються при перекладі без зносок, адже події Другої світової війни були добре відомими як італійським, так і українським дітям: Era un partigiano ferito a una gamba, e il bambino corse a chiamare sua madre [10] Виявилося, шо то стогне партизан. Його поранило в ногу. Хлопчина побіг по малу [18]. Крім того, у цьому прикладі варто звертнути увагу й на членування речення. Італійській мові властиві довгі, розлогі речення, що також зустрічаються і в дитячій літературі, а для української казкової традищї притаманні більш короткі речення - до такої адаптації і вдався Іван Дзюб при перекладі, застосувавши таким чином стратегію одомашнення.

Також певні реалії італійського побуту вказують на те, що період створення першотвору, на відміну від фольклорних казок, є сучасним читачам оригіналу та перекладу: Quando si fu stancato di quel gioco Tonino usci dalla scuola e sali su un filobus, naturalmente senza pagare il biglietto, perché il fattorino non poteva vederlo [10] - Haбaвившись донесхочу, Тоніно вийшов зі школи й сів у тролейбус [18] та Nacque una gran discussione, e quasi tutti $i$ passeggeri pronunciarono parole di fuoco contro l'azienda tranviaria [10] - Kвumka він, звісно, не взяв, знаючи, шо кондуктор його не бачить. Зчинився галір, пасажири почали лаяти тролейбусне управління [18]. Ці реалії також відтворюються перекладачем без змін.

У казках Джанні Родарі більш сучасними $є$ також і реалії на позначення професій та титулів: Giunto nella città vicina, si fece indicare la casa del governatore, quella del presidente e quella del giudice $e$ andò a far visita a quegli illustri personaggi e anche a loro toccò il naso con un dito o duе [10] - Показали йолу будинок губернатора, прокурора та судді, він відвідав иих титулованuх осіб $i$ полаиав їхні носи [18]. При перекладі реалії presidente Іван Дзюб залучає смисловий розвиток, адже мова йде про головного прокурора, а головою держави був король.

Окремо варто зупинитися на відтворенні реалій італійської кухні. У певних випадках перекладач їх відтворюе дослівно, без зносок, хоча малоймовірно, що у сімдесятих роках у Радянському Союзі ці реалії були настільки поширені та зрозумілі для читачів дитячого віку: Domani tua sorella si sposa e vuol mangiare polenta e lepre [10] - Завтра твоя сестра виходить заліж, буде весілля, й годилося б наварити поленти 3 заячиною [18]. Проте, перекладач використовує трансорормацію генералізащії для доволі відомих страв італійської кухні: ...dopo aver mangiato gli spaghetti sgranocchiava anche il piatto, e lo digeriva 
a meraviglia [10] - ...що, виївши макарони, улинав тарілку $i$ чудово все перетравлював [18]. Також перекладач вдавався до рекатегоризації при відтворенні назв італійських спеціалітетів сирів - відповідно до панівної у той період традиції форомування назв таких продуктів: Somiglia al parmigiano o al gorgonzola? [10] - Схожий на парліджанський чи горгондзольський сир? [18] Таким чином, було І.П. Дзюб послуговувався стратегією одомашнення. Також Іван Дзюб використовуе описовий переклад при відтворенні назви ще одного відомого італійського сиру - моцарела: ...Pulcinella sognava montagne di spaghetti e pianure di mozzarella, ma non si arrendeva [10] ...хоч Пульчінеллі снилися гори спагетті та рівнини свіжого сиру, він не здавався [18]. Іван Дзюб залучає генералізацію при відтворенні відомого італійського брошняного виробу: No: vai dalla nonna a portarle questa focaccia [10] - Hi. Йди до бабусі та занеси їй пиріжка [18]. Наведена реалія не відіграє смислоутворюючої ролі, тож відтворення focaccia як пиріжок є слушним, адже не ускладнює розуміння тексту казки.

Незвичною реалією в тексті казки "Tante domande" ("Запитайко") е nuво: Perché $i$ francobolli non bevono birra? [10] - Чолу марки не n'ють пива? [18] Вирогідно, Іван Дзюб вирішив відтворити без змін таку незвичну для казкового дискурсу реалію через те, що вона не мала жодного зв'язку із вжитком серед дітей і в той самий час була відомою, а також вказуе на те, що переклад було здіснено до Антиалкогольної кампанії М. Горбачова.

Як було згадано вище, творам для дітей характерна гра слів. У казці "A inventare i numeri” (“Хто вигадає більше чисел?”):

\begin{tabular}{|c|c|}
\hline $\begin{array}{l}\text { tre per uno Trento } \\
\text { e Belluno } \\
\text { tre per due bistecca di bue } \\
\text { tre per tre latte e caffè } \\
\text { tre per quattro cioccolato } \\
\text { tre per cinque malelingue } \\
\text { tre per sei patrizi e plebei } \\
\text { tre per sette torta a fette } \\
\text { tre per otto piselli e risotto } \\
\text { tre per nove scarpe nuove } \\
\text { tre per dieci pasta e ceci } \\
{[10]}\end{array}$ & $\begin{array}{l}\text { три по однолу-йди додолу } \\
\text { три по два-он сова } \\
\text { три по три -носа втри } \\
\text { три по чотири - дзвоник } \\
\text { до квартири } \\
\text { три по п'ять-зеллі п'ядь } \\
\text { три по шість-непроханий } \\
\text { гість } \\
\text { три по сіл- -иукерки всіл } \\
\text { три по вісіл - джлелі в } \\
\text { стрісі } \\
\text { три по дев'ять - качка й } \\
\text { лебідь } \\
\text { три по десять - діток } \\
\text { пестять } \\
{[18]}\end{array}$ \\
\hline
\end{tabular}

Перекладач не відтворюе семантику оригіналу, проте передає форму, тобто римовані вирази замість результатів множення. Такий переклад може вважатися адекватним.

Для дитячої літератури є притаманним вживання вигаданих слів, утворених на основі ономатопеї: Senti questi: uno stramilione di biliardoni, un ottone di millantoni, un meravigliardo e un meraviglione [10] - Ось послухай, що я вигадав: один зверхмільйон більярдонів, один восьлільйон тисячонів, один чудольярд $i$ один чудольйон [18], які I. Дзюб відтворюе при перекладі як за змістом, так і за формою, корень перекладених слів відповідає значенню кореня італійського слова, а запозичені суфікси дозволяють зберегти фрорму італійського слова, завдяки чому відтворюеться також і національний колорит першотвору.
У випадку, коли гра слів не несе смислового навантеження, перекладач використовуе транслітерацію: Maraschi, barabaschi, pippirimoschi, disse il primo [10] - Mapacki, барабаскi, ninipiмоскі, - сказав перший [18].

Іншим прикладом гри слів є: Un giorno o l'altro, egli confidava ad Arlecchino, - taglio la corda [10] Сьогодні чи завтра переріжу мотузочки, - сказав він Арлекінові [18]. Італійський вислів tagliare la corda, окрім прямого значення, яке зустрічається у перекладі Івана Дзюба має також і переносне втекти. В оригіналі головний герой - лялька-маріонетка Пульчінелла - хоче втекти від хазяїна лялькового театру, перерізавши мотузочки, на яких він тримається, тож дослівний переклад $є$ слушним, адже надалі згадуватимуться й ножищі, якими Пульчінелла себе вивільнив.

Ще одним випадком гри слів у казках Джанні Родарі є наступний: Quanto costa questa pasta? Due tirate d'orecchi [10] - Скільки коштують иі макарони - Два шиглі в лоб [18]. При перекладі відбувається одомашнення, адже due tirate d'orecchi дослівно перекладається як два посликування за вуха, але для української культури у подібних випадках зазвичай згадуються щиглі в лоба. Оскільки цей елемент також не впливає на сюжет, така заміна з боку перекладача є цілком виправданою.

Як зазначалося на початку, літературна, або авторська казка може містити алюзії на інші твори світової літератури: Il signor Gogol ha raccontato la storia di un naso di Leningrado, che se ne andava a spasso in carrozza e ne combinava di tutti i colori [10] - Микола Гоголь розповів про одного петербурзького носа, шо виїжджав у кареті на прогулянку [18]. У перекладі Іван Дзюб уточнюе ім'я згаданого в оригіналі письменника і використовуе інший прикметник, що вказує на походження носа, адже це відповідає творові Миколи Гоголя. Таким чином перекладач послуговуеться стратегією одомашнення.

Висновки 3 даного дослідження. На основі наведених прикладів можна зробити висновок, що літературна або авторська казка засновуеться на фольклорній і певною мірою наслідує iii за структурою та окремими елементами, як-то чарівні події та герої, але збагачуе її образністю, розмаїттям характерів та мотивів, а також реалій. Крім того, до мовної та концептуальної картин світу додається також і індивідуально-авторська, що втілюе цінності, погляди та творчий підхід конкретного митця. При перекладі італійських авторських казок українською мовою варто звертати увагу на реципієнта перекладу, на приховані змісти, особливості введення реалій та елементів чарівного у текст казки, а також на жанрово-стилістичну домінанту, яка є характероною для літературної традиції цільової культури. При перекладі збірки Джанні Родарі “Казки по теледону” Іван Дзюб використовуе обидві стратегії - очуження та одомашнення - відповідно до важливості кожного окремого елементу для сюжету казки, та повністю відтворюе структурні компоненти першотворів, за виключенням випадків компресії фрінальної фрормули, завдяки чому відбувається пристосування тексту оригіналу до традицій цільової культури, тобто підкреслюється повчальна функція казки, властива українському казковому дискурсу. 


\section{Список літератури:}

1. Bolte J., Polivka G. Anmefklingen zu den Kinderund Hausmarchen der Bruder Grimm. Leipzig, $1913-1932$.

2. Бюлер К. Духовное развитие ребенка. Москва, 1924. 556 с.

3. Claudio Marazzini. Fiaba colta e fiaba popolare. URL: http://www.treccani.it/scuola/tesine/fiaba/2.html (дата звернення: 10.03.2021).

4. Венгренівська М.А. Творча майстерня перекладача: Збірка теоретичних розвідок : Навч. посібник / М.А. Венгренівська, А.Д. Гнатюк, КНУТШ. Київ : РВЦ Київський університет, 1998. 89 с.

5. Dizionario della lingua italiana LARUS. Bergamo, 1993. 1415 p.

6. Дунаєвська Л.Ф. Українська народна казка. Київ, 1987. 127 с.

7. Enciclopedia Zanichelli: Dizionario enciclopedico di arti, scienze, tecniche, lettere, filosofia, storia, geografia, diritto, economia. Bologna, 2000. 2074 p.

8. Fiabe e Favole per bambini. URL: http://www.lefiabe.com/ (дата звернення: 12.02.2021).

9. Fiabe e favole. Le differenze tra la fiaba e la favola. URL: http://www.lefavole.org/fiabe.htm (дата звернення: 19.01.2021).

10. Gianni Rodari. Favole al telefono. Trieste, 1993. URL: https://didatticattivablog.files.wordpress.com/2016/11/ gianni-rodari-favole-al-telefono.pdf (дата звернення: 15.04.2021).

11. Здражко А.Є. Переклад дитячої літератури: “очуження” чи "одомашнення". Studia linguistica: збірник наукових праць. Київ, 2011. Вип. 5, ч. 1. С. 549-552.

12. Здражко А.Є. Сучасні підходи до перекладу текстів для дітей. Мовні $і$ концептуальні картини світу. Київ, 2012. Вип. 41, ч. 2. С. 69-75.

13. Літературознавчий словник-довідник. Літературознавча енциклопедія / за ред. Ю.І. Коваліва. Т. 1. Київ, $2007.579 \mathrm{c.}$

14. Липовецкий М.Н. Поэтика литературной сказки (на материале русской литературы 1920-1980-х годов). Свердловск, 1992.184 с.

15. Никифоров А.И. Сказка и сказочник. Москва, 2008. 376 с.

16. Овчинникова Л.И. Русская литературная сказка XX века (история, классификация, поэтика) : монография. Москва, 2001. 324 с.

17. Пропп. В.Я. Морфология сказки. Москва, 1969. 166 с.

18. Родарі Дж. Казки по телефону (переклад з італійської - Іван Дзюб). Київ, 1977. URL: https://www.ae-lib.org.ua/ texts/rodari_telephone_tales_ua.htm (дата звернення: 05.03.2021).

19. Словник української мови. Київ, 1980. URL: http://sum.in.ua/ (дата звернення: 18.03.2021).

20. Чуковский К.И. Высокое искусство. Москва, 2001. URL: http://www.chukfamily.ru/kornei/prosa/knigi/vysokoe (дата звернення: 18.03.2021).

\section{References:}

1. Bolte J., Polivka G. (1913-1932) Anmefklingen zu den Kinderund Hausmarchen der Bruder Grimm. Leipzig.

2. Byuler K. (1924) Dukhovnoe razvitie rebenka [Spiritual development of the child]. Moscow. (in Russian)

3. Claudio Marazzini. Fiaba colta e fiaba popolare. Available at: http://www.treccani.it/scuola/tesine/fiaba/2.html (accessed 10 March 2021).

4. Venhrenivska M.A., Hnatiuk A.D. (1998) Tvorcha maisternia perekladacha: Zbirka teoretychnykh rozvidok [Creative translator's workshop: Antology of theoretical studies]. Kyiv: RVTS Kyivskyi universytet. (in Ukrainian)

5. Dizionario della lingua italiana LARUS (1993). Bergamo.

6. Dunaievska L.F. (1987) Ukrainska narodna kazka [Ukrainian folktale]. Kyiv. (in Ukrainian)

7. Zanichelli (2000). Enciclopedia Zanichelli: Dizionario enciclopedico di arti, scienze, tecniche, lettere, filosofia, storia, geografia, diritto, economia. Bologna: Zanichellli.

8. Fiabe e Favole per bambini. Available at: http://www.lefiabe.com/ (accessed 12 February 2021).

9. Fiabe e favole. Le differenze tra la fiaba e la favola. Available at: http://www.lefavole.org/fiabe.htm (accessed 19 January 2021).

10. Gianni Rodari (1993) Favole al telefono Trieste. Available at: https://didatticattivablog.files.wordpress.com/2016/11/ gianni-rodari-favole-al-telefono.pdf (accessed 15 April 2021).

11. Zdrazhko A.Ye. (2011) Pereklad dytiachoi literatury: "ochuzhennia" chy "odomashnennia" [Translation of children's literature: "foreignisation" and "domestication"]. Studia linguistica, vol. 5, pp. 549-552. Kyiv. (in Ukrainian)

12. Zdrazhko A.Ye. (2012) Suchasni pidkhody do perekladu tekstiv dlia ditei [Moderna approaches to the translation of texts for children]. Movni i konceptualjni kartyny svitu [Linguistic and conceptual pictures of the world]. Kyiv, vol. 41, pp. 69-75. (in Ukrainian)

13. Kovaliv Ju.I. (ed.) (2007) Literaturoznavchyj slovnyk-dovidnyk [Dictionary - reference book on literature studies]. Kyiv, vol. 1. (in Ukrainian)

14. Lipovetskiy M.N. (1992) Poetika literaturnoy skazki (na materiale russkoy literatury 1920-1980-kh godov) [Poetics of a literary tale: based on Russian literature of the 1920-1980s]. Sverdlovsk. (in Russian)

15. Nikiforov A.I. (2008) Skazka i skazochnik [Fairytale and tale-teller]. Moscow. (in Russian)

16. Ovchinnikova L.I. (2001) Russkaya literaturnaya skazka XX veka (istoriya, klassifikatsiya, poetika) [Russian literary tale of the XX century (history, classification, poetics)]. Moscow. (in Russian)

17. Propp V.Ya. (1969) Morfologiya skazki [The morphology of the fairytale]. Moscow. (in Russian)

18. Rodari Dzh. (1977) Kazky po telefonu (pereklad z italijsjkoji - Ivan Dzjub) [Fairytales by phone (translation from Italian - Ivan Dzjub)]. Kyiv: Veselka. Available at: https://www.ae-lib.org.ua/texts/rodari_telephone_tales_ua.htm (accessed 05 March 2021).

19. Bilodid I.K. (1980) Slovnyk ukrajinsjkoji movy [Dictionary of the Ukrainian language]. Kyiv: Naukova Dumka. Available at: http://sum.in.ua/ (accessed 18 March 2021).

20. Chukovskiy K.I. (2001) Vysokoe iskusstvo [High art]. Moscow. Available at: http://www.chukfamily.ru/kornei/ prosa/knigi/vysokoe (accessed 18 March 2021). 